\title{
Recent advances in combating Nipah virus
}

\author{
Kendra Johnson ${ }^{1} \quad$ Michelle $\mathrm{Vu}^{1} \quad$ Alexander N. Freiberg ${ }^{2 *}$ \\ ${ }^{1}$ Department of Microbiology and Immunology, University of Texas Medical Branch, Galveston, Texas, USA \\ ${ }^{2}$ Department of Pathology, University of Texas Medical Branch, Galveston, Texas, USA
}

\begin{abstract}
Over the past 20 years, Nipah virus (NiV) has emerged as a significant, highly pathogenic bat-borne paramyxovirus causing severe respiratory disease and encephalitis in humans, and human-to-human transmission has been demonstrated in multiple outbreaks. In addition to causing serious illness in humans, $\mathrm{NiV}$ is a zoonotic pathogen capable of infecting a wide range of other mammalian species, including pigs and horses. While NiV has caused less than 700 human cases since its discovery in 1998/1999, the involvement of intermediate agricultural hosts can result in significant economic consequences. Owing to the severity of disease, capacity for human-to-human transmission, zoonotic potential, and lack of available approved therapeutic treatment options, NiV has been listed by the World Health Organization in their Blueprint list of priority pathogens as one of the eight most dangerous pathogens to monitor and prepare countermeasures to prevent a pandemic. Here, we discuss progress towards the development of therapeutic measures for the treatment of NiV infection and disease.
\end{abstract}

\section{Keywords}

Nipah virus, henipavirus, respiratory disease, encephalitis, antivirals, antibodies

\section{Peer Review}

The peer reviewers who approve this article are:

1. Michael Lo, Centers for Disease Control and Prevention, Atlanta, GA, USA

Competing interests: No competing interests were disclosed.

2. Hector Aguilar-Carreno, Department of Microbiology and Immunology, Cornell University College of Veterinary Medicine, Ithaca, NY, USA

Competing interests: No competing interests were disclosed. 
*Corresponding author: Alexander N. Freiberg (anfreibe@utmb.edu)

Competing interests: The authors declare that they have no competing interests.

Grant information: This work was partially supported by the National Institutes of Health (NIH) (grant numbers R33 AI102267 and R21 AI111042 to A.N.F.). K.J. was supported by a NIH T32 Biodefense training fellowship (AI060549).

The funders had no role in study design, data collection and analysis, decision to publish, or preparation of the manuscript.

Copyright: (C) 2021 Freiberg AN et al. This is an open access article distributed under the terms of the Creative Commons Attribution License, which permits unrestricted use, distribution, and reproduction in any medium, provided the original work is properly cited.

How to cite this article: Johnson $\mathrm{K}, \mathrm{Vu}$ M, and Freiberg AN. Recent advances in combating Nipah virus. Faculty Reviews 2021 10:(74) https:/doi. $\operatorname{org} / 10.12703 / \mathrm{r} / 10-74$

Published: 29 Sep 2021, Faculty Reviews 10:(74) https://oi.org/10.12703/r/10-74 


\section{Introduction}

Nipah virus (NiV), and the related Hendra virus $(\mathrm{HeV})$, are highly pathogenic, emerging zoonotic bat-borne RNA viruses belonging to the henipavirus (HNV) genus within the Paramyxoviridae family. NiV was first identified in 1998/1999 in Malaysia in an outbreak of encephalitis in pig farmers ${ }^{1,2}$, resulting in the culling of more than 1 million pigs, which contributed to controlling the outbreak but ultimately had a significant economic impact ${ }^{3}$. Subsequently, NiV has caused nearly annual outbreaks in Bangladesh and India ${ }^{2,4-9}$. Two genetically divergent strains of $\mathrm{NiV}$ have been identified, $\mathrm{NiV}$ Malaysia (NiV-M) and $\mathrm{NiV}$ Bangladesh (NiV-B), with the latter being the currently circulating $\operatorname{strain}^{10}$. In humans, infection with $\mathrm{NiV}$ is associated with severe, acute respiratory illness, as well as acute, relapsed, or late-onset encephalitis, and case fatality rates range from 40 to $100 \%{ }^{11,12}$. Treatment of patients is mainly reliant on supportive care, with maintenance of airways, breathing, and circulation as well as fluid and electrolyte balance. To date, only an agricultural subunit vaccine for the related $\mathrm{HeV}$ is licensed ${ }^{13}$. While primarily associated with spillover events from the natural fruit bat reservoir host, frequent human-to-human transmission has been reported ${ }^{4,14,15}$. Because of the extreme pathogenicity and pandemic potential of $\mathrm{NiV}$, the lack of approved human treatments and vaccines, and its potential for use in (agro)bioterrorism, it is crucial to develop vaccines and therapeutics for $\mathrm{NiV}^{3,16}$. This review outlines recent advances in the development of therapeutics and treatments for $\mathrm{NiV}$ infection.

\section{Monoclonal antibodies}

Currently, the human cross-reactive monoclonal antibody $(\mathrm{mAb}) \mathrm{m} 102.4$ is the most promising monoclonal antibody therapeutic treatment for $\mathrm{NiV}$ infection. This antibody was affinity matured to strongly neutralize both $\mathrm{NiV}$ and $\mathrm{HeV}$ attachment glycoprotein $\mathrm{G}$ by blocking the interaction of $\mathrm{G}$ with the host cellular entry receptors Ephrin B2 and B3 ${ }^{17,18}$. m102.4 has demonstrated protection against $\mathrm{HNV}$ infection in both ferret and non-human primate (NHP) models of infection. A single intravenous (IV) infusion of m102.4 10 hours after intranasal infection with $\mathrm{NiV}$ afforded full protection in a ferret model of disease ${ }^{19}$. Post-exposure studies in the African Green Monkey (AGM) model were even more promising. Here, m102.4 was fully protective in AGMs when treatment was initiated up to 3 days post-infection with $\mathrm{HeV}$ and 5 days post-infection with NiV-M, even after onset of clinical symptoms and viremia ${ }^{20,21}$. In both studies, a second dose was administered 2 days after the initial one. Interestingly, a study comparing pathogenicity of NiV-M and NiV-B in the AGM model indicated that the treatment window for NiV-B may be shorter as compared to NiV-M. Commensurate with an accelerated onset of severe disease in NiV-B compared to NiV-M, m102.4 was protective only when administered up to 3 days post-infection with NiV-B. Infected animals receiving initial treatment at 5 days post-infection succumbed to disease $^{22}$.

Results from these studies justified the usage of m102.4 in humans for compassionate use as well as a phase I clinical trial. To date, m102.4 has been administered 14 times for compassionate therapy following high-risk exposure to $\mathrm{HNVs}^{23,24}$. No treatment-related adverse effects were reported in any of these cases. Additionally, no recipients of the antibody developed disease, although it is impossible to determine whether this was related to m102.4 treatment. The combination of compassionate therapy for post-exposure treatment in patients and the promising preclinical data from animal studies led to the assessment of safety, tolerability, and immunogenicity of m102.4 in healthy adults in a phase I clinical trial ${ }^{23}$. This study found that the dosages tested were safe and well tolerated. Also, no serious adverse effects resulting in participant withdrawal were reported. Pharmacokinetics evaluations concluded that m102.4 remained active at levels capable of virus neutralization for at least 8 days post-administration. Immunogenicity tests found that no anti-m102.4 antibodies were generated. Although this trial was small (30 participants) and unable to evaluate protective efficacy, the safety and tolerability demonstrated in this study make m102.4 one of the most promising therapeutic options for the treatment of patients with HNV exposure.

Another potential antibody therapy currently under investigation is h5B3.1, a humanized, cross-reactive, neutralizing $\mathrm{mAb}$ that targets the fusion glycoprotein $\mathrm{F}$ of $\mathrm{NiV}$ and $\mathrm{HeV}$, blocking the conformational change required to facilitate membrane fusion and virus infection ${ }^{25,26}$. Previous studies had demonstrated protective efficacy of anti-F mouse polyclonal antibodies or mAbs against $\mathrm{NiV}$ and $\mathrm{HeV}$ challenge of hamsters, supporting development of the humanized h5B3.1 mAb as a potential therapeutic for use in humans ${ }^{27,28}$. Intraperitoneal administration of h5B3.1 at days 1 and 3 , as well as 3 and 5 post-infection, demonstrated protective efficacy against lethal challenges with either $\mathrm{NiV}$ or $\mathrm{HeV}$ in ferrets. The authors of the study also proposed a combination treatment of h5B3.1 and m102.4 antibodies, targeting both viral surface glycoproteins, as a therapeutic strategy moving forward to minimize the chances of the emergence of escape mutants. However, as in vivo characterization of h5B3.1 is currently limited, more studies are required before potential introduction in human patients alone or in combination with m102.4.

\section{Antiviral drugs}

\section{In humans}

The only therapeutic option that has been utilized clinically in NiV patients is ribavirin, a broad-spectrum nucleoside analogue $e^{2,29,30}$. Ribavirin is currently licensed for the treatment of respiratory syncytial virus infection, hepatitis $\mathrm{C}$, and viral hemorrhagic fevers and is included on the WHO essential medicines $\operatorname{list}^{31-34}$. During the initial 1998/1999 outbreak in Malaysia, an open-label trial of ribavirin was conducted in which 140 patients received treatment. Patients treated prior to the trial or who refused ribavirin treatment served as the control group $(\mathrm{n}=54)^{29}$. In this study, administration of ribavirin was associated with a $36 \%$ reduction in mortality and fewer neurological deficits in survivors. In an earlier description of the clinical features presented during that outbreak, it was stated that there appeared to be no significant difference in 
outcome with ribavirin treatment ${ }^{2}$. More recently, ribavirin was utilized during the 2018 outbreak in Kerala, India, which consisted of a total of 23 cases and only two survivors ${ }^{4,30}$. Both survivors had received oral ribavirin, out of a subset of six patients who received ribavirin therapy ${ }^{30,35,36}$. This corresponds to a $20 \%$ reduction in mortality, compared to the $100 \%$ mortality observed in a group of six patients not receiving ribavirin. However, the sample size was too small to draw a conclusion on the efficacy of ribavirin against $\mathrm{NiV}$. Ribavirin was also administered as a post-exposure prophylactic to eight healthcare workers who were exposed to infected patients without sufficient PPE during the 2018 outbreak $^{30}$. None developed $\mathrm{NiV}$ disease; however, most experienced mild to moderate adverse side effects from the treatment. Overall, ribavirin's efficacy in the 2018 Kerala outbreak was inconclusive. Moreover, studies of $\mathrm{NiV}$ infection in animal models were not promising. Ribavirin administered either alone or in combination with chloroquine (an antimalarial drug) was not protective in the hamster model ${ }^{37,38}$.

\section{In animal models}

No other therapeutics have been utilized for the treatment of $\mathrm{NiV}$ infection in patients, and only a few others have been evaluated in animal models. Remdesivir (GS-5734; Veklury ${ }^{\circledR}$ ), a nucleotide analog that has demonstrated broad-spectrum antiviral activity against filoviruses, paramyxoviruses, and coronaviruses, is one of them ${ }^{39-41}$. In a lethal challenge AGM model for NiV-B, remdesivir led to $100 \%$ survival when intravenously administered daily starting 24 hours after infection and continued for 12 days $^{41}$. Two out of the total four NHPs involved in the study developed only mild respiratory signs of disease that resolved by day 14 post-infection. At termination of the study at 92 days post-infection, viral RNA was found in the brain of one animal. While these results are highly encouraging, future studies need to be performed to further evaluate remdesivir's antiviral efficacy. Remdesivir was also recently included in a clinical trial evaluating Ebola therapeutics in the context of the 2018 Democratic Republic of Congo outbreak ${ }^{42}$. Although this study found it to be less effective against Ebola virus disease compared to $\mathrm{mAb}$ treatments, remdesivir did appear to be safe. Recently, remdesivir has been utilized as a compassionate therapy for the treatment of patients with SARS-CoV-2, although the efficacy is still unclear ${ }^{43-45}$. Multiple clinical trials are currently ongoing ${ }^{46}$.

Additional antivirals with promising efficacy have been evaluated for the treatment of NiV infection in small animal models. Favipiravir (T-705; Avigan ${ }^{\circledR}$ ) is a small molecule purine ana$\log$ antiviral that is licensed for the management of emerging pandemic influenza infections in $\mathrm{Japan}^{47}$. In the Syrian golden hamster model, favipiravir demonstrated full protection against lethal infection with NiV-M when administered immediately after infection and continued daily for 14 days ${ }^{48}$. None of the treated animals developed any clinical signs of disease throughout the course of the study, and no viral RNA or pathological changes in tissues were observed. Future studies need to evaluate the post-exposure antiviral efficacy of favipiravir. Griffithsin (GRFT), a homodimeric high-mannose oligosaccharide-binding lectin, is currently being evaluated in clinical trials as a topical microbicide against human immunodeficiency virus 1 (HIV-1 $)^{49,50}$. In cell culture studies, GRFT, as well as a synthetic trimeric tandemer $(3 \mathrm{mG})$ and an oxidation-resistant GRFT (Q-GRFT), demonstrated antiviral activity against $\mathrm{NiV}$ in the nanomolar range ${ }^{51}$. The prophylactic potential of $3 \mathrm{mG}$ and Q-GRFT was evaluated in the Syrian hamster model for NiV-B and resulted in overall survival rates of $15 \%$ and $35 \%$, respectively. Future studies are needed to further evaluate and develop Q-GRFT for the treatment of NiV infection.

\section{In vitro}

4'azidocytidine (R1479), a cytidine analog shown to have broadspectrum antiviral activity against flaviviruses and a pneumovirus, exhibited strong antiviral effects against $\mathrm{NiV}$ in vitro in the low micromolar range $\mathrm{e}^{52-55}$. However, balapiravir, the prodrug of R1479, did not show promising results in clinical trials treating flavivirus infections; the trials were discontinued owing to poor prodrug efficacy and negative side effects ${ }^{53,56,57}$. Derivatives of R1479 resulted in more encouraging results compared to R1479. The 2'-monofluoro- and 2'difluoro-modified deriva.tives of R1479 (2'F-4'N3-C and 2'diF-4'N3-C) exhibited up to 20-fold increased antiviral effects on $\mathrm{NiV}$ than R1479 in vitro and revealed less cytotoxicity ${ }^{58}$. The greater antiviral efficacy and lower cytotoxic effects of 2'F-4'N3-C and 2'diF-4'N3-C make the R1479 derivatives a more promising therapeutic avenue compared with R1479 for future evaluation.

4'-chloromethyl-2'-deoxy-2'-fluorocytidine (ALS-8112) is another antiviral cytidine analog and the parent nucleoside of lumicitabine, which has undergone phase I and phase II clinical trials to treat respiratory syncytial virus infections ${ }^{59-61}$. ALS-8112 displayed strong antiviral effects against $\mathrm{NiV}$ in vitro in the low micromolar range, with minimal cytotoxic effects in multiple cell lines except for human peripheral blood mononuclear and lymphoblastoid cells ${ }^{59}$. However, caution must be taken in optimizing ALS-8112 dosage to prevent neutropenia and lymphopenia if further evaluated as a potential antiviral against $\mathrm{NiV}$ infection in animal models.

In addition to targeting the viral replication machinery, peptide fusion inhibitors aimed at inhibiting viral fusion with the host cellular membrane have been evaluated as well. Optimized lipopeptide fusion inhibitors (with cholesterol or tocopherol conjugated to the polypeptide using dPEG) exhibited protection against lethal $\mathrm{NiV}$ infection in Syrian golden hamsters (50\% survival) and AGMs (33\% survival) after prophylactic administration $^{62,63}$. Enfuvirtide (FuzeonTM) is an FDA-approved analogous therapeutic for HIV-1 and is also a lipopeptide fusion inhibitor which has the potential to move forward as an effective antiviral ${ }^{64,65}$. Future development of potent lipopeptide inhibitors for $\mathrm{NiV}$ infection is needed.

One other strategy that has demonstrated potential is the use of defective interfering particles (DIPs), which contain 
defective genomes that alter the dynamics of a viral population to inhibit $\mathrm{NiV}$ replication. In vitro assays demonstrate that naturally occurring and in silico-designed DIPs decrease viral titer 100 -fold and reduce cytopathic effects in Vero cells $^{66}$. While currently exploratory as a form of treatment for NiV, DIPs should undergo future animal studies. Studies using DIPs for influenza A virus have been promising ${ }^{67-70}$.

\section{Discussion}

$\mathrm{NiV}$ remains a pathogen of significant concern because of its high pathogenicity, demonstrated potential for human-to-human transmission, and lack of approved treatments. From the range of antivirals tested so far against infectious $\mathrm{NiV}$, only two have demonstrated therapeutic efficacy in the NHP model: the m102.4 monoclonal antibody and the nucleotide analogue remdesivir. m102.4 is the only potential therapeutic that has been evaluated in humans specifically for the treatment of NiV. Currently, m102.4 is perhaps the most promising therapeutic option from an efficacy standpoint; however, the requirement for cold chain storage and the intravenous route of administration may not make it the most practical for use in field outbreaks. Ribavirin has been utilized as a compassionate therapy and a post-exposure prophylactic in humans, but its efficacy remains unclear. Small molecule antivirals, specifically nucleoside analogues, have demonstrated good efficacy in blocking $\mathrm{NiV}$ infection and need to be further evaluated for their therapeutic potential. However, evaluation of antiviral efficacy against $\mathrm{NiV}$ in patients is complicated by the infrequency of cases, and alternative pathways to licensure may be necessary. As many of the currently characterized antiviral treatment candidates appear to have a limited window for treatment efficacy in animal models, timely diagnosis and initiation of treatment will be crucial. Additionally, combinatorial therapy of mAbs and small molecule antivirals might be an effective treatment strategy, as well as the development and approval of a vaccine for $\mathrm{NiV}$ and the prevention of spillover events. In addition to the antiviral therapeutics discussed in this review, four vaccine candidates that demonstrated effectiveness in disease-relevant animal models have received funding through the Coalition of Epidemic Preparedness Innovation (CEPI) to be further evaluated in phase I and II clinical trials ${ }^{71}$. These include a $\mathrm{HeV}$ glycoprotein subunit vaccine for the prevention of $\mathrm{NiV}$ infection, which is currently in phase I clinical trials ${ }^{72,73}$, and three recombinant viral vector vaccines, which are in preclinical development ${ }^{74-77}$. Additionally, with the recent rise to prominence of mRNA vaccines during the SARS-CoV-2 pandemic, this technology may be useful in the future as a potential strategy for $\mathrm{NiV}$ vaccines. In one study, a single dose of a lipid nanoparticle nucleoside-modified messenger RNA vaccine encoding the soluble $\mathrm{HeV}$ glycoprotein protected up to $70 \%$ of Syrian hamsters from lethal NiV challenge, indicating the promise of this particular platform for future prevention of $\mathrm{NiV}$ disease $\mathrm{i}^{78}$.

It should also be noted that a large number of novel HNVs and henipa-like viruses have recently been identified. The expanding diversity of HNVs raises some questions about preparedness for the potential for new spillovers and the emergence of new pathogenic HNVs, which may be important to consider in the context of therapeutic and vaccine development. While m102.4 and h5B3.1 demonstrate cross-protection for pathogenic HNVs, $\mathrm{NiV}$ and $\mathrm{HeV}$, it has recently been reported that antibodies elicited by $\mathrm{G}$ proteins of $\mathrm{NiV}$ and $\mathrm{HeV}$ have very limited cross-reactivity and no cross-protection for new members Mojiang virus (MojV) and Ghana virus $(\mathrm{GhV})^{79}$. This study proposed a fusion protein strategy containing epitopes from $\mathrm{NiV}, \mathrm{HeV}, \mathrm{MojV}$, and $\mathrm{GhV}$ as a broad-spectrum vaccine that elicited cross-protection against all four viruses. It may be important to identify strategies for the generation of pan-HNV treatments in the event of the emergence of new pathogenic HNVs.

1. Chua KB, Goh KJ, Wong KT, et al.: Fatal encephalitis due to Nipah virus among pig-farmers in Malaysia. Lancet. 1999; 354(9186): 1257-9. PubMed Abstract | Publisher Full Text

2. Goh KJ, Tan CT, Chew NK, et al:: Clinical features of Nipah virus encephalitis among pig farmers in Malaysia. N Engl J Med. 2000; 342(17): 1229-35. PubMed Abstract | Publisher Full Text

3. Lam SK: Nipah virus--a potential agent of bioterrorism? Antiviral Res. 2003; 57(1-2): 113-9. PubMed Abstract | Publisher Full Text

4. Arunkumar G, Chandni R, Mourya DT, et al.: Outbreak of Nipah Virus Disease in Kerala, India, 2018. SSRN Journal. 2018. Publisher Full Text

5. Chadha MS, Comer JA, Lowe L, et al:: Nipah virus-associated encephalitis outbreak, Siliguri, India. Emerg Infect Dis. 2006; 12(2): 235-40. PubMed Abstract | Publisher Full Text | Free Full Text

6. Chan KP, Rollin PE, Ksiazek TG, et al:: A survey of Nipah virus infection among various risk groups in Singapore. Epidemiol Infect. 2002; 128(1): 93-8. PubMed Abstract | Publisher Full Text | Free Full Text

7.

Gurley ES, Montgomery JM, Hossain MJ, et al:: Person-to-person transmission of Nipah virus in a Bangladeshi community. Emerg Infect Dis. 2007; 13(7): 1031-7.

PubMed Abstract | Publisher Full Text | Free Full Text | Faculty Opinions Recommendation

8. Homaira N, Rahman M, Hossain MJ, et al:: Nipah virus outbreak with person-to-person transmission in a district of Bangladesh, 2007. Epidemiol Infect. 2010; 138(11): 1630-6.

PubMed Abstract | Publisher Full Text

9. Hossain MJ, Gurley ES, Montgomery JM, et al.: Clinical presentation of nipah virus infection in Bangladesh. Clin Infect Dis. 2008; 46(7): 977-84. PubMed Abstract | Publisher Full Text

10. Soman Pillai V, Krishna G, Valiya Veettil M: Nipah Virus: Past Outbreaks and Future Containment. Viruses. 2020; 12(4): 465. PubMed Abstract | Publisher Full Text | Free Full Text | Faculty Opinions Recommendation

11. Kenmoe S, Demanou M, Bigna JJ, et al.: Case fatality rate and risk factors 
for Nipah virus encephalitis: A systematic review and meta-analysis. J Clin Virol. 2019; 117: 19-26.

PubMed Abstract | Publisher Full Text | Faculty Opinions Recommendation

12. Escaffre $O$, Borisevich V, Rockx B: Pathogenesis of Hendra and Nipah virus infection in humans. J Infect Dev Ctries. 2013; 7(4): 308-11. PubMed Abstract | Publisher Full Text

13. Middleton $\mathrm{D}$, Pallister $\mathrm{J}$, Klein $\mathrm{R}$, et al:: Hendra virus vaccine, a one health approach to protecting horse, human, and environmental health. Emerg Infect Dis. 2014; 20(3): 372-9.

PubMed Abstract | Publisher Full Text | Free Full Text

14. Clayton BA: Nipah virus: Transmission of a zoonotic paramyxovirus. Curr Opin Virol. 2017; 22: 97-104.

PubMed Abstract | Publisher Full Text

15. Ching PKG, de los Reyes VC, Sucaldito MN, et al.: Outbreak of henipavirus infection, Philippines, 2014. Emerg Infect Dis. 2015; 21(2): 328-31. PubMed Abstract | Publisher Full Text | Free Full Text

16. Luby SP: The pandemic potential of Nipah virus. Antiviral Res. 2013; 100(1): 38-43.

PubMed Abstract | Publisher Full Text | Faculty Opinions Recommendation

17. N Xu K, Rockx B, Xie Y, et al:: Crystal structure of the Hendra virus attachment $\mathrm{G}$ glycoprotein bound to a potent cross-reactive neutralizing human monoclonal antibody. PLoS Pathog. 2013; 9(10): e1003684. PubMed Abstract | Publisher Full Text | Free Full Text | Faculty Opinions Recommendation

18. Zhu Z, Bossart KN, Bishop KA, et al.: Exceptionally potent cross-reactive neutralization of Nipah and Hendra viruses by a human monoclonal antibody. $J$ Infect Dis. 2008; 197(6): 846-53.

PubMed Abstract | Publisher Full Text | Free Full Text

19. Bossart KN, Zhu Z, Middleton D, et al:: A neutralizing human monoclonal antibody protects against lethal disease in a new ferret model of acute nipah virus infection. PLoS Pathog. 2009; 5(10): e1000642. PubMed Abstract | Publisher Full Text | Free Full Tex

20. Bossart KN, Geisbert TW, Feldmann $\mathrm{H}$, et al:: A neutralizing human monoclonal antibody protects african green monkeys from hendra virus challenge. $\mathrm{Sci}$ Transl Med. 2011; 3(105): 105ra103.

PubMed Abstract | Publisher Full Text | Free Full Text

21. Geisbert TW, Mire CE, Geisbert JB, et al.: Therapeutic treatment of Nipah virus infection in nonhuman primates with a neutralizing human monoclonal antibody. Sci Transl Med. 2014; 6(242): 242 ra82. PubMed Abstract | Publisher Full Text | Free Full Text

22. Mire CE, Satterfield BA, Geisbert JB, et al:: Pathogenic Differences between Nipah Virus Bangladesh and Malaysia Strains in Primates: Implications for Antibody Therapy. Sci Rep. 2016; 6: 30916 . PubMed Abstract | Publisher Full Text | Free Full Text | Faculty Opinions Recommendation

23. Playford EG, Munro T, Mahler SM, et al.: Safety, tolerability, pharmacokinetics, and immunogenicity of a human monoclonal antibody targeting the G glycoprotein of henipaviruses in healthy adults: $A$ first-in-human, randomised, controlled, phase 1 study. Lancet Infect Dis. 2020; first-in-human,
20(4): 445-54.

PubMed Abstract | Publisher Full Text | Faculty Opinions Recommendation

24. Broder $\mathrm{CC}, \mathrm{Xu} \mathrm{K}$, Nikolov DB, et al:: $\mathbf{A}$ treatment for and vaccine against the deadly Hendra and Nipah viruses. Antiviral Res. 2013; 100(1): 8-13. PubMed Abstract | Publisher Full Text | Free Full Text

25. Mire CE, Chan YP, Borisevich V, et al:: A Cross-Reactive Humanized Monoclonal Antibody Targeting Fusion Glycoprotein Function Protects Ferrets Against Lethal Nipah Virus and Hendra Virus Infection. $J$ Infect Dis. 2020; 221(Suppl 4): S471-S479.

PubMed Abstract | Publisher Full Text | Free Full Text |

Faculty Opinions Recommendation

26. D Dang HV, Chan YP, Park YJ, et al:: An antibody against the F glycoprotein inhibits Nipah and Hendra virus infections. Nat Struct Mol Biol. 2019; 26(10): 980-987.

PubMed Abstract | Publisher Full Text | Free Full Text | Faculty Opinions Recommendation

27. Guillaume V, Wong KT, Looi RY, et al:: Acute Hendra virus infection: Analysis of the pathogenesis and passive antibody protection in the hamster model. Virology. 2009; 387(2): 459-65.

PubMed Abstract | Publisher Full Text

28. Guillaume $\mathrm{V}$, Contamin $\mathrm{H}$, Loth $\mathrm{P}$, et al:: Antibody prophylaxis and therapy against Nipah virus infection in hamsters. J Virol. 2006; 80(4): 1972-8. PubMed Abstract | Publisher Full Text | Free Full Text

29. Chong HT, Kamarulzaman A, Tan CT, et al.: Treatment of acute Nipah encephalitis with ribavirin. Ann Neurol. 2001; 49(6): 810-3. PubMed Abstract | Publisher Full Text

30. Banerjee S, Niyas VKM, Soneja M, et al.: First experience of ribavirin postexposure prophylaxis for Nipah virus, tried during the 2018 outbreak in Kerala, India. J Infect. 2019; 78(6): 491-503.

PubMed Abstract | Publisher Full Text
31. Bausch DG, Hadi CM, Khan SH, et al:: Review of the literature and proposed guidelines for the use of oral ribavirin as postexposure prophylaxis for Lassa fever. Clin Infect Dis. 2010; 51(12): 1435-41.

PubMed Abstract | Publisher Full Text | Free Full Text

32. Fisher-Hoch SP, Khan JA, Rehman S, et al:: Crimean Congo-haemorrhagic fever treated with oral ribavirin. Lancet. 1995; 346(8973): 472-5.

PubMed Abstract | Publisher Full Text

33. Snell NJ: Ribavirin--current status of a broad spectrum antiviral agent. Expert Opin Pharmacother. 2001; 2(8): 1317-24. PubMed Abstract | Publisher Full Text

34. Organization WH: WHO model list of essential medicines - 21st list. 2019. Reference Source

35. Arunkumar G, Devadiga S, McElroy AK, et al:: Adaptive Immune Responses in Humans During Nipah Virus Acute and Convalescent Phases of Infection. Clin Infect Dis. 2019; 69(10): 1752-6. PubMed Abstract | Publisher Full Text | Faculty Opinions Recommendation

36. Chandni R, Renjith TP, Fazal A, et al:: Clinical Manifestations of Nipah VirusInfected Patients Who Presented to the Emergency Department During an Outbreak in Kerala State in India, May 2018. Clin Infect Dis. 2020; 71(1): 152-7. PubMed Abstract | Publisher Full Text | Faculty Opinions Recommendation

37. Freiberg AN, Worthy MN, Lee B, et al.: Combined chloroquine and ribavirin treatment does not prevent death in a hamster model of Nipah and Hendra virus infection. J Gen Virol. 2010; 91(Pt 3): 765-72. PubMed Abstract | Publisher Full Text | Free Full Text

38. Georges-Courbot MC, Contamin H, Faure C, et al.: Poly(I)-poly(C12U) but not ribavirin prevents death in a hamster model of Nipah virus infection. Antimicrob Agents Chemother. 2006; 50(5): 1768-72. PubMed Abstract | Publisher Full Text | Free Full Text

39. Lo MK, Jordan R, Arvey A, et al:: GS-5734 and its parent nucleoside analog inhibit Filo-, Pneumo-, and Paramyxoviruses. Sci Rep. 2017; 7: 43395 PubMed Abstract | Publisher Full Text | Free Full Text

40. Sheahan TP, Sims AC, Graham RL, et al:: Broad-spectrum antiviral GS-5734 inhibits both epidemic and zoonotic coronaviruses. Sci Transl Med. 2017; 9(396): eaal3653.

PubMed Abstract | Publisher Full Text | Free Full Text

41. Clo MK, Feldmann F, Gary JM, et al.: Remdesivir (GS-5734) protects African green monkeys from Nipah virus challenge. Sci Transl Med. 2019; 11(494): eaau9242.

PubMed Abstract | Publisher Full Text | Free Full Text |

Faculty Opinions Recommendation

42. Mulangu S, Dodd LE, Davey RT, et al.: A Randomized, Controlled Trial of Ebola Virus Disease Therapeutics. N Engl J Med. 2019; 381(24): 2293-2303. PubMed Abstract | Publisher Full Text | Faculty Opinions Recommendation

43. Grein J, Ohmagari N, Shin D, et al.: Compassionate Use of Remdesivir for Patients with Severe Covid-19. N Engl J Med. 2020; 382(24): 2327-36. PubMed Abstract | Publisher Full Text | Free Full Text | Faculty Opinions Recommendation

44. Veklury (remdesivir) EUA Letter of Approval (10/22/2020). FDA. 2020 Reference Source

45. Okoli GN, Rabbani R, Copstein L, et al:: Remdesivir for coronavirus disease 2019 (COVID-19): A systematic review with meta-analysis and trial sequential analysis of randomized controlled trials. Infect Dis (Lond). 2021; 53(9): 691-699. PubMed Abstract | Publisher Full Text | Free Full Text Faculty Opinions Recommendation

46. Gilead: Remdesivir Clinical Trials.

Reference Source

47. Furuta Y, Gowen BB, Takahashi K, et al:: Favipiravir (T-705), a novel viral RNA polymerase inhibitor. Antiviral Res. 2013; 100(2): 446-54. PubMed Abstract | Publisher Full Text | Free Full Text

48. Dawes BE, Kalveram B, Ikegami T, et al.: Favipiravir (T-705) protects against Nipah virus infection in the hamster model. Sci Rep. 2018; 8(1): 7604. PubMed Abstract | Publisher Full Text | Free Full Text | Faculty Opinions Recommendation

49. Mori T, O'Keefe BR, Sowder RC 2nd, et al:: Isolation and characterization of griffithsin, a novel HIV-inactivating protein, from the red alga Griffithsia sp. J Biol Chem. 2005; 280(10): 9345-53.

PubMed Abstract | Publisher Full Text

50. clincaltrials.gov. Reference Source

51. Lo MK, Spengler JR, Krumpe LRH, et al:: Griffithsin Inhibits Nipah Virus Entry and Fusion and Can Protect Syrian Golden Hamsters From Lethal Nipah Virus Challenge. J Infect Dis. 2020; 221(Supplement_4): S480-S492. PubMed Abstract | Publisher Full Text | Free Full Text | Faculty Opinions Recommendation

52. Klumpp K, Lévêque V, Le Pogam S, et al:: The novel nucleoside analog R1479 (4'-azidocytidine) is a potent inhibitor of NS5B-dependent RNA synthesis and hepatitis C virus replication in cell culture. J Biol Chem. 2006; 281(7): 3793-9. PubMed Abstract | Publisher Full Text 
53. Nguyen NM, Tran CNB, Phung LK, et al.: A randomized, double-blind placebo controlled trial of balapiravir, a polymerase inhibitor, in adult dengue patients. $J$ Infect Dis. 2013; 207(9): 1442-50.

PubMed Abstract | Publisher Full Text | Free Full Text

54. Wang G, Deval J, Hong J, et al.: Discovery of 4'-chloromethyl-2'-deoxy-3', 5'-di-O-isobutyryl-2'-fluorocytidine (ALS-8176), a first-in-class RSV polymerase inhibitor for treatment of human respiratory syncytial virus infection. J Med Chem. 2015; 58(4): 1862-78. PubMed Abstract | Publisher Full Text

55. Hotard AL, He B, Nichol ST, et al:: 4'-Azidocytidine (R1479) inhibits henipaviruses and other paramyxoviruses with high potency. Antiviral Res. 2017; 144: 147-52.

PubMed Abstract | Publisher Full Text | Free Full Text |

Faculty Opinions Recommendation

56. Roberts SK, Cooksley G, Dore GJ, et al:: Robust antiviral activity of R1626, a novel nucleoside analog: A randomized, placebo-controlled study in patients with chronic hepatitis C. Hepatology. 2008; 48(2): 398-406. PubMed Abstract | Publisher Full Text

57. Nelson DR, Zeuzem $\mathrm{S}$, Andreone $\mathrm{P}$, et al:: Balapiravir plus peginterferon alfa-2a $(40 K D) /$ ribavirin in a randomized trial of hepatitis $C$ genotype 1 patients. Ann Hepatol. 2012; 11(1): 15-31. PubMed Abstract | Free Full Text

58. Lo MK, Jordan PC, Stevens S, et al:: Susceptibility of paramyxoviruses and filoviruses to inhibition by 2'-monofluoro- and 2'-difluoro-4'-azidocytidine analogs. Antiviral Res. 2018; 153: 101-13.

PubMed Abstract | Publisher Full Text | Free Full Text | Faculty Opinions Recommendation

59. Lo MK, Amblard F, Flint M, et al.: Potent in vitro activity of B-D-4'-chloromethyl-2'-deoxy-2'-fluorocytidine against Nipah virus. Antiviral Res. 2020; 175: 104712.

PubMed Abstract | Publisher Full Text | Free Full Text | Faculty Opinions Recommendation

60. DDeVincenzo JP, McClure MW, Symons JA, et al:: Activity of Oral ALS-008176 in a Respiratory Syncytial Virus Challenge Study. N Engl J Med. 2015; 373(21) 2048-58.

PubMed Abstract | Publisher Full Text | Faculty Opinions Recommendation

61. Patel K, Kirkpatrick CM, Nieforth KA, et al.: Respiratory syncytial virus-A dynamics and the effects of lumicitabine, a nucleoside viral replication inhibitor, in experimentally infected humans. $J$ Antimicrob Chemother. 2019; 74(2): 442-52.

PubMed Abstract | Publisher Full Text | Faculty Opinions Recommendation

62. Mathieu C, Augusto MT, Niewiesk S, et al:: Broad spectrum antiviral activity for paramyxoviruses is modulated by biophysical properties of fusion inhibitory peptides. Sci Rep. 2017; 7: 43610.

PubMed Abstract | Publisher Full Text | Free Full Text

63. Mathieu C, Porotto M, Figueira TN, et al.: Fusion Inhibitory Lipopeptides Engineered for Prophylaxis of Nipah Virus in Primates. J Infect Dis. 2018; 218(2): 218-27.

PubMed Abstract | Publisher Full Text | Free Full Text

64. Lalezari JP, Henry K, O'Hearn M, et al.: Enfuvirtide, an HIV-1 fusion inhibitor, for drug-resistant HIV infection in North and South America. N Engl J Med. 2003; 348(22): 2175-85.

PubMed Abstract | Publisher Full Text
65. Kilby JM, Hopkins S, Venetta TM, et al:: Potent suppression of HIV-1 replication in humans by T-20, a peptide inhibitor of gp41-mediated virus entry. Nat Med. 1998; 4(11): 1302-7.

PubMed Abstract | Publisher Full Text

66. Welch SR, Tilston NL, Lo MK, et al.: Inhibition of Nipah Virus by Defective Interfering Particles. J Infect Dis. 2020; 221(Suppl 4): S460-S470.

PubMed Abstract | Publisher Full Text | Faculty Opinions Recommendation

67. Dimmock NJ, Dove BK, Scott PD, et al: Cloned defective interfering influenza virus protects ferrets from pandemic 2009 influenza $A$ virus and allows protective immunity to be established. PLoS One. 2012; 7(12): e49394. PubMed Abstract | Publisher Full Text | Free Full Text

68. Dimmock NJ, Dove BK, Meng B, et al.: Comparison of the protection of ferrets against pandemic 2009 influenza A virus (H1N1) by 244 DI influenza virus and oseltamivir. Antiviral Res. 2012; 96(3): 376-85.

PubMed Abstract | Publisher Full Text | Free Full Text

69. Scott PD, Meng B, Marriott AC, et al:: Defective interfering influenza A virus protects in vivo against disease caused by a heterologous influenza B virus. J Gen Virol. 2011; 92(Pt 9): 2122-32.

PubMed Abstract | Publisher Full Tex

70. Scott PD, Meng B, Marriott AC, et al.: Defective interfering influenza virus confers only short-lived protection against influenza virus disease: Evidence for a role for adaptive immunity in DI virus-mediated protection in vivo. Vaccine. 2011; 29(38): 6584-91. PubMed Abstract | Publisher Full Text | Free Full Text

71. Innovations CfEP. Reference Source

72. clinicaltrials.gov: Safety and Immunogenicity of a Nipah Virus Vaccine. Reference Source

73. Vaccines A: Clinical-Stage Prophylactic Vaccines.

74. CEPI: CEPI awards up to US\$43.6 million to Public Health Vaccines, LLC. for development of a single-dose Nipah virus vaccine candidate. 2019. Reference Source

75. Christodoulou M: CEPI awards contract worth up to US\$ $\mathbf{3 1}$ million to The University of Tokyo to develop vaccine against Nipah virus. 2019. Reference Source

76. Christodoulou M: CEPI Awards Contract Worth Up To USD\$19 million to Oxford University and Janssen Vaccines to Develop MERS, Lassa, and Nipah Vaccines. 2018 Reference Source

77. CEPI: Our portfolio. Reference Source

78. Lo MK, Spengler JR, Welch SR, et al.: Evaluation of a Single-Dose Nucleoside-Modified Messenger RNA Vaccine Encoding Hendra Virus-Soluble Glycoprotein Against Lethal Nipah virus Challenge in Syrian Hamsters. J Infect Glycoprotein Against Lethal Nipah
Dis. 2020; 221(Suppl 4): S493-S498. PubMed Abstract | Publisher Full Text | Free Full Text | Faculty Opinions Recommendation

79. Li Y, Li R, Wang M, et al:: Fc-Based Recombinant Henipavirus Vaccines Elicit Broad Neutralizing Antibody Responses in Mice. Viruses. 2020; 12(4): 480.

PubMed Abstract | Publisher Full Text | Free Full Text | Faculty Opinions Recommendation 